\title{
Impact of Coal Mining On Environment and Natural Resources - Causes and Potential Effects
}

\author{
Muhammadi Tughyan* \\ Lecturer in Department of Oil and Gas Production, Geology and Mines Engineering Faculty, Jawzjan \\ University, Sheberghan, Afghanistan
}

*Corresponding Authors: Muhammadi Tughyan, Lecturer in Department of Oil and Gas Production, Geology and Mines Engineering Faculty, Jawzjan University, Sheberghan, Afghanistan

\begin{abstract}
Coal mining and consumption play a significant role in the economic and social development of any country. Coal mining industry generates a large volume of gangue wastes, from which a considerable number of toxic heavy metals could be released during weathering of the waste under the joint effects of water, microorganisms, vegetation. Irrespective of the actual methods of coal mining being used, mining processes unavoidably bring about land-surface disturbances, and increased mining for expanded coal supplies will inevitably lead to extended land disturbances. With the continuous improvement of mechanized mining technology, many thousands of tons of large-scale mines have been put into production. Mining induced sharply increasing of coal mine water drainage and decreasing of groundwater table. these findings highlight the impacts of coal mining on soil properties and the findings can greatly contribute to understanding soil conditions and the environmental risks associated with coal mining.
\end{abstract}

Keywords: Coal Mining; soil pollution, land subsidence, land disturbance, water pollution

\section{INTRODUCTION}

The world production of coal is approximately $3.5 \times 10^{9} \mathrm{t} \mathrm{yr}^{-1}$, most of which is used to produce $38 \%$ of the world's electricity, and coal is an important energy resource for steel, cement and thermal power plants (Ram et al., 2010; Mukhopadhyay et al., 2016). Coal production has important economic and social benefits; however, it generates large amounts of coal mine spoils, and waste rocks which oxidize under atmospheric conditions and release metal-rich effluents to the surrounding environment. This causes serious problems to surrounding water-soil bodies (Equeenuddin et al., 2010; Chuncai et al., 2014; Sahoo et al., 2012). Coal mining and consumption play a significant role in the economic and social development of any country. It is well known that various toxic elements exist in coal refuse and fly ash, and these toxic elements can be released and enter the soil through coal industry activities, including production and accumulation of a large amount of gangue, discharge of sewage, and emissions from coal-fired power plants and coal transportation (Candeias et al., 2011). This article reviews the impact of coal mining on environment, soil heavy metal pollution and land subsidence by referring the earlier reports.

\section{EFFECT ON ENVIRONMENT}

Coal mining industry generates a large volume of gangue wastes, from which a considerable number of toxic heavy metals could be released during weathering of the waste under the joint effects of water, microorganisms, vegetation, sunlight radiation and heat (Larocque and Rasmussen, 2011). These hazardous substances enter the ecosystem by a variety of pathways where they could be detrimental to crops and animals, and might be taken up by human through direct contact (ingestion, dermal absorption and inhalation) or food chains (Sun et al., 2013). Coal mining activities are unavoidably linked with the excavation of huge amounts of dump rocks, which are of great environmental concern due to the potential for production of acidic and metal-rich drainage. Burning coal gives rise to airborne compounds such as fly ash and bottom ash, which contain heavy metals that settle down or wash out from the atmosphere into the land and thus contaminate soil. This, in turn, degrades the chemical and microbiological quality of soil (Bhuiyan et al., 2010; Sahoo et al., 2010; Wuana and Okieimen, 2011; Zhang et al., 2013), and subsequently creates a threat to humans 
and the ecosystem through direct contact with contaminated soils and the food chain because trace elements can be transferred from soil to plants and impact on crop growth and food safety. Environmental studies of coal mining areas were conducted by many researchers from USA (Finkelman, 1999; Finkelman and Gross, 1999), Europe (Szczepanska and Twardowska, 1987; Panov et al., 1999) and China (Ding et al., 2001). Knowledge of the spatial distribution of toxic elements in soil in the entire mining area is necessary.

\section{Soil Heavy Metal Pollution}

Soil is important nonrenewable resources that act as origin and pool of various contaminants. Soil contamination by heavy metals is an important issue, and various activities such as agricultural, urbanization, and industrialization are responsible for enhancing the heavy metal content in the soil (Hu et al., 2013; Keshavarzi and Kumar, 2018; Kumar et al., 2019; Zou et al., 2015).

It was shown that numerous studies of soil heavy metal pollution caused by mining activities have been carried out over the past few years. For instance, Ge et al., (2016) analyzed and assessed the ecological risk from seven heavy metals, namely, $\mathrm{Cd}, \mathrm{Hg}, \mathrm{As}, \mathrm{Cu}, \mathrm{Pb}, \mathrm{Cr}$ and $\mathrm{Zn}$, that were present in soils surrounding a coal waste pile. Bhuiyan et al. (2010) made a complete evaluation of the pollution level in the coal mine affected agricultural soils of Barapukuria coal mine region in Bangladesh. They have shown that the average concentrations of $\mathrm{Ti}, \mathrm{Mn}, \mathrm{Zn}, \mathrm{Pb}, \mathrm{As}, \mathrm{Fe}, \mathrm{Rb}, \mathrm{Sr}, \mathrm{Nb}$ and $\mathrm{Zr}$ exceeded the world normal averages and in some cases $\mathrm{Mn}, \mathrm{Zn}$, As and $\mathrm{Pb}$ exceeded the toxic limit and the entire area has high magnitude of contamination level. Yu et al. (2002) assessed spatio-temporal variation of heavy metal concentration in reclaimed soil of Fushun coal mine of China.

In a study by Guo et al., (2018), the soil quality index (SQI) values were calculated to quantify the influence of slope position because of coal mining subsidence on soil quality using principal component analysis. The SQI values irregularly varied with different slope positions. It was mainly because the slope changed the spatial distribution of soil properties, and preference of cropping activity by local farmers can also intensify the distribution.

\section{LAND SUBSIDENCE}

Land subsidence can directly affect the soil water and texture due to surface deformation, and cause an extensive decrease in the groundwater level. In this sense, land subsidence triggered by underground mining can have an immediate and long-lasting impact on the soil quality, and thus on the ecosystem services. Land subsidence causes substantial ecological and environmental problems, such as water and soil erosion, aggravation of land degradation, and declines in soil quality (Chen et al., 2018; Shepley et al., 2008; Wu et al, 2009). The soil structure and soil properties are both disturbed by land subsidence, which increases the average internal fraction angle value and reduces the average values of water and organic matter in soil (Yang et al, 2016). In addition, land subsidence alters soil hydraulic properties, increases soil micropores, and decreases the field capacity (Wang et al., 2017). Mining subsidence increases the soil infiltration depth and evaporation, while reducing the water-holding capacity of the upper soil layers. The loss of soil water inevitably leads to severe ecological deterioration. Furthermore, the plant density, coverage, and biomass are affected by land subsidence after mining (Yang et al., 2018). Therefore, the ecosystem is disturbed by land subsidence and the soil quality further changes.

Soil texture is measured using the percentages of clay, silt, and sand, and is critical for understanding the transportation and storage of soil water and nutrients, as well as the mineralization of organic matter content. Land subsidence causes dense surface cracks and this may result in the loss of silt and clay, an increased sand percentage, and a tendency for soil to undergo desertification. Additionally, the SWC in the subsidence areas was significantly lower than that in the control areas in the current study. This reduction in SWC could be attributed to the dense surface cracks caused by coal seam exploitation destroying the soil structure and increasing the total soil porosity; thus, land subsidence increases the evaporation and infiltration capacity of soil.

\section{LAND DISTURBANCE}

Irrespective of the actual methods of coal mining being used, mining processes unavoidably bring about land-surface disturbances, and increased mining for expanded coal supplies will inevitably lead to extended land disturbances. Such disturbed land tends to create a negative effect on the surrounding 
environment and reduces its economic value. The character of the disturbance depends upon the disposition of the mined strata, and upon the methods used to mine them. Continued improvement of coal-mining methods is associated with the exploitation of deeper coal seams (below $1000 \mathrm{~m}$ in deep mining operations and a few hundred metres in surface or strip-mine operations). Generally speaking, progress in mining has led to greater use of open coal extraction methods which produce larger-scale disturbances on the earth's surface. At the same time, research and development has provided greatly improved engineering and biological methods of landscape reclamation.

\section{IMPACT OF COAL Mining ON WATER QUALiTY}

Coal mining activities can directly affect the quality of the water or indirectly through processes which may show its consequences at a later stage in the life of the mine. The gravity of the impact of these activities depend on a number of factors like the geology of the area, the mineral constituents of the coal, the composition of the overburden, scale of operations, rainfall distribution, etc. Some of the major sources of water pollution in coal mining areas are;

Mine water drainage/Acid mine drainage

Coal seams sometimes have high concentration of pyrites which in presence of water and oxygen undergo oxidation to give sulphuric acid thereby increasing the acidity and $\mathrm{pH}$ of the water used. This water contaminates the other water bodies and the ground water when discharged from the mine.

Loose material runoffs

The process of mining is usually associated with generation of large amount of dust and, the mineral and overburden excavated are converted to loose material. Winds pick up these dust particles along with loose material and deposit them on water bodies. Loose material is also carried by the streams running through the mines which eventually meet the main course or end into a water reservoir causing pollution in both cases.

Oil and fuel spills

Oils and fuels are used for the machinery and equipment used in the mining operations. These oils and fuel sometimes leak away or washed off during cleaning and maintenance. The water used for washing or during rains, these oils and fuels contaminate the nearby water bodies.

Pollutant leaching from overburden dump

Overburden dump is the waste material which has to be removed before the mineral resources can be salvaged. The waste materials can contain pollutants in the form of heavy metals of other chemicals which leach out during the rains and pollute the surrounding areas.

Sewage discharges A mine employs hundreds of people, who's domestic and sanitary water needs have to be taken care of. The sewage from the domestic and sanitary use of water can cause pollution if they discharges untreated.

With the continuous improvement of mechanized mining technology, many thousands of tons of large-scale mines (in the yield of thousands of tons) have been put into production. Mining induced sharply increasing of coal mine water drainage and decreasing of groundwater table, and moreover with each passing year, the substantial growth of drainage volume because of overlying aquifer was connected by a vertical fracture.

\section{Fugitive EMisSiONS}

The transport of coal in all its forms necessarily involves fugitive dusts, even though precautionary measures are increasingly taken. It is generally estimated that $0.02 \%$ of the coal loaded is lost as fugitive dust and a similar percentage lost at unloading. Until recently, loss during transportation has not been estimated, but more work is enabling these losses now to be assessed. Fugitive emissions of coal particulates and other air pollutants occur during loading, unloading and en route. It is now estimated that about $50 \%$ of the coal dust losses occur during journey time and $25 \%$ at loading and $25 \%$ at unloading. There is some loss also due to spillage. Some estimates suggest that $0.2 \mathrm{~kg} \mathrm{t} " 1$ is emitted during loading and a similar amount during unloading. Losses in transit may be from 0.05 to $1.0 \%$ of the total coal involved. For this reason wind guards are used, moistened coal transported or latex polymer or asphalt sprays used. Some wagons incorporate flip-top lids 


\section{CONCLUSION}

In short, these findings highlight the impacts of coal mining on soil properties and the findings can greatly contribute to understanding soil conditions and the environmental risks associated with coal mining.

\section{REFERENCES}

[1] Bhuiyan MAH, Parvez L, Islam MA, Dampare SB, Suzuki S (2010). Heavy metal pollution of coal mineaffected agricultural soils in the northern part of Bangladesh. Journal of Hazardous Materials, 173: 384392.

[2] Candeias C, Ferreira de Silva E, Salgueiro AR, Pereira HG, Patinha C, Matos JX, Avila PH (2011). Assessment of soil contamination by potentially toxic elements in the aljustrel mining area in order to implement soil reclamation strategies. L. Degrad. Dev. 22: 565-585.

[3] Chen Y, Zhang J, Zhou A, Yin B. (2018). Modeling and analysis of mining subsidence disaster chains based on stochastic Petri nets. Nat. Hazards., 92, 19-41.

[4] Chuncai Z, Guijian L, Dun W, Ting F, Ruwei W, Xiang F. (2014). Mobility behavior and environmental implications of trace elements associated with coal gangue: a case study at the Huainan Coalfield in China. Chemosphere. 95:193-199.

[5] Ding Z, Zheng B, Long J, Belkin HE, Finkelman RB, Chen C, Zhou D, Zhou Y. (2001). Geological and geochemical characteristics of high arsenic coals from endemic arsenosis areas in southwestern Guizhou Province, China. Appl. Geochem. 16: 1353-1360.

[6] Equeenuddin SM, Tripathy S, Sahoo PK, Panigrahi MK. (2010). Hydrogeochemical characteristics of acid mine drainage and water pollution at Makum Coalfield, India. J Geochem Expl. 3: 75-82.

[7] Finkelman RB. (1999). Trace elements in coal. Biol. Trace Elem. Res. 67: 197-204.

[8] Finkelman RB, Gross PMK. (1999). The types of data needed for assessing the environmental and human health impacts of coal. Int. J. Coal Geol. 40: 91-101.

[9] Ge H, Feng Y, Li Y, Yang WL, Gong N. (2016). Heavy metal pollution diagnosis and ecological risk assessment of the surrounding soils of coal waste pile at Naluo Coal Mine, Liupanshui, Guizhou. International Journal of Mining Reclamation and Environment 30: 312-318.

[10] Guo X, Zhao T, Chang W, Xiao C, He Y. (2018). Evaluating the effect of coal mining subsidence on the agricultural soil quality using principal component analysis. Chilean Journal of Agricultural Research, 78(2), 173-182.

[11] Hu Y, Liu X, Bai J, Shih K, Zeng EY, Cheng H. (2013). Assessing heavy metal pollution in the surface soils of a region that had undergone three decades of intense industrialization and urbanization. Environmental Science and Pollution Research, 20: 6150-6159.

[12] Keshavarzi A, Kumar V. (2018). Ecological risk assessment and source apportionment of heavy metal contamination in agricultural soils of Northeastern Iran. International Journal of Environmental Health Research, 1-17.

[13] Kumar V, Sharma A, Kaur P, Sidhu GPS, Bali AS, Bhardwaj R, Cerda A. (2019). Pollution assessment of heavy metals in soils of India and ecological risk assessment: A state-of-the-art. Chemosphere. 216: 449462.

[14] Larocque ACL, Rasmussen PE. (2011). An overview of trace metals in the environment, from mobilization to remediation. Environ. Geol. 138: 3497-3507.

[15] Mukhopadhyay S, Masto RE, Yadav A, George J, Ram LC, Shukla SP. (2016). Soil quality index for evaluation of reclaimed coal mine spoil. Science of the Total Environment 542: 540-550.

[16] Panov BS, Dudik AM, Shevchenko OA, Matlak ES. (1999). On pollution of the biosphere in industrial areas: the example of the Donets coal Basin. Int. J. Coal Geol. 40: 199-210.

[17] Ram LC, Masto RE (2010). An appraisal of the potential use of fly ash for reclaiming coal mine spoil. Journal of Environmental Management 91:603-617.

[18] Sahoo PK, Tripathy S, Equeenuddin Sk Md, Panigrahi MK. (2012). Geochemical characteristics of coal mine discharge vis-à-vis behavior of rare earth elements at Jaintia Hills Coalfield, Northeastern India. J Geochem Expl. 112: 235-243.

[19] Sahoo PK, Tripathy S, Equeenuddin SM, Panigrahi MK. (2010) Influence of different forms of acidities on soil microbiological properties and enzyme activities at an acid mine drainage contaminated site. J Hazard Mater. 179: 966-975.

[20] Shepley MG, Pearson AD, Smith GD, Banton CJ. (2008). The impacts of coal mining subsidence on groundwater resources management of the East Midlands Permo-Triassic Sandstone aquifer, England. Q. J. Eng. Geol. Hydroge. 41, 425-438. 
[21] Sun C, Liu J, Wang Y, Sun L, u H. (2013) Multivariate and geostatistical analyses of the spatial distribution and sources of heavy metals in agricultural soil in Dehui, Northeast China. Chemosphere 92: 517-523.

[22] Szczepanska J, Twardowska I. (1987). Coal mine spoil tips as a large area source of water contamination. Adv. Min. Sci. Technol. 2: 267-280.

[23] Wang J, Wang P, Qin Q, Wang H. (2017). The effects of land subsidence and rehabilitation on soil hydraulic properties in a mining area in the Loess Plateau of China. Catena.159, 51-59.

[24] Wu Q, Pang J, Qi S, Li Y, Han C, Liu T, Huang L. (2009). Impacts of coal mining subsidence on the surface landscape in Longkou city, Shandong Province of China. Environ. Earth Sci. 59, 783-791.

[25] Wuana RA, Okieimen FE. (2011). Heavy metals in contaminated soils: a review of sources, chemistry, risks and best available strategies for remediation. ISRN Ecology 2011.

[26] Yang D, Bian Z, Lei S. (2016). Impact on soil physical qualities by the subsidence of coal mining: A case study in Western China. Environ. Earth Sci. 75, 652.

[27] Yang Y, Erskine PD, Zhang S, Wang Y, Bian Z, Lei S. (2018). Effects of underground mining on vegetation and environmental patterns in a semi-arid watershed with implications for resilience management. Environ. Earth Sci. 77, 605.

[28] Yu J, Liu J, Wang Z, Li X, Zhang X. (2002). Spatial-temporal variation of heavy metal elements content in covering soil of reclamation area in Fushun coal mine. Chinese Geographical Science, 12: 268-272.

[29] Zhang ZY, Abuduwaili J, Jiang FQ. (2013). Determination of occurrence characteristics of heavy metals in soil and water environments in tianshan mountains, central Asia. Anal Lett. 46: 2022-2031.

[30] Zou J, Dai W, Gong S, Ma Z. (2015). Analysis of spatial variations and sources of heavy metals in farmland soils of Beijing suburbs. PLoS One, 10(2): e0118082.

Citation: Muhammadi Tughyan, "Impact of Coal Mining On Environment and Natural Resources - Causes and Potential Effects ", International Journal of Mining Science (IJMS), vol. 6, no. 1, pp. 32-36, 2020. Available: DOI: http://dx.doi.org/ 10.20431/2454-9428.0601003

Copyright: (C) 2020 Authors. This is an open-access article distributed under the terms of the Creative Commons Attribution License, which permits unrestricted use, distribution, and reproduction in any medium, provided the original author and source are credited. 